\title{
Enhancement of Platelet Function by Superoxide Anion
}

\author{
Robert I. Handin, Richard Karabin, and Grace J. Boxer \\ From the Division of Hematology, Department of Medicine, Peter Bent Brigham Hospital and \\ Department of Medicine, Harvard Medical School, Boston, Massachusetts 02115
}

\begin{abstract}
A B S T RACT During the aerobic conversion of xanthine to uric acid by xanthine oxidase, superoxide anion and hydrogen peroxide are produced along with the hydroxyl radical. Our studies demonstrate that washed human platelets incubated with xanthine and xanthine oxidase aggregated and released $\left[{ }^{14} \mathrm{C}\right]-$ serotonin. Aggregation and release were dependent on the duration of exposure to xanthine oxidase as well as the concentration of enzyme. Both reactions were inhibited by the superoxide scavenger enzyme superoxide dismutase but not by catalase, or the free radical scavenger mannitol, suggesting that they were induced by superoxide anion. Superoxide-dependent release was inhibited by prior incubation of platelets with $1 \mathrm{mM}$ EDTA, $1 \mu \mathrm{M}$ prostaglandin $\mathrm{E}_{1}$, or $1 \mathrm{mM}$ dibutyryl cyclic AMP, but was unaffected by $1 \mathrm{mM}$ acetylsalicylic acid or $1 \mu \mathrm{M}$ indomethacin. After prolonged incubation with xanthine and xanthine oxidase there was also efflux of up to $15 \%$ of intraplatelet ${ }^{51} \mathrm{Cr}$, a cytosol marker. This leakage was prevented by the addition of catalase to the media but not by superoxide dismutase. Incubation with xanthine and xanthine oxidase did not produce malonyldialdehyde, the three-carbon fatty acid fragment produced during prostaglandin endoperoxide synthesis and lipid peroxidation. Prior exposure of platelets to low fluxes of superoxide anion lowered the threshold for release by subsequent addition of thrombin, suggesting a synergistic effect. We conclude that superoxide-dependent aggregation and release may be a physiologically important method to modulate hemostatic reactions particularly in areas of inflammation or vessel injury which could have high local concentrations of superoxide anion.
\end{abstract}

Dr. Handin is a Cancer Research Scholar, Massachusetts Division of the American Cancer Society.

Received for publication 7 September 1976 and in revised form 29 December 1976.

\section{INTRODUCTION}

Superoxide anion $\left(\mathrm{O}_{2}^{-}\right)^{1}$ is produced during a variety of intracellular oxidation-reduction reactions by the univalent reduction of molecular oxygen (1). Superoxide can then generate hydrogen peroxide $\left(\mathrm{H}_{2} \mathrm{O}_{2}\right)$ : $\mathrm{O}_{2}^{-}+\mathrm{O}_{2}^{-}+2 \mathrm{H}^{+} \rightarrow \mathrm{H}_{2} \mathrm{O}_{2}+\mathrm{O}_{2}$ and the hydroxyl radical $(\mathrm{OH} \cdot): \mathrm{H}_{2} \mathrm{O}_{2}+\mathrm{O}_{2}^{-} \rightarrow \mathrm{OH}^{-}+\mathrm{OH}^{-}+\mathrm{O}_{2}(2) . \mathrm{H}_{2} \mathrm{O}_{2}$ may also be produced by the direct two-electron reduction of oxygen. $\mathrm{O}_{2}^{-}, \mathrm{H}_{2} \mathrm{O}_{2}$, and $\mathrm{OH} \cdot$ are highly reactive molecules which could potentially damage surrounding cellular structures and subcellular organelles. Aerotolerant cells have the enzymes superoxide dismutase (SOD) (1) and catalase which can reduce the concentration of $\mathrm{O}_{2}^{-}+\mathrm{H}_{2} \mathrm{O}_{2}$ and thereby protect the cell. However, these intracellular enzymes cannot protect cells from attack by extracellular sources of reduced oxygen or free radicals. Recently, both $\mathrm{O}_{2}^{-}$and $\mathrm{H}_{2} \mathrm{O}_{2}$ have been shown to diffuse from granulocytes during phagocytosis $(3,4)$. These observations suggest at least one source of extracellular oxidants which could damage other blood cells and neighboring vascular tissue.

In support of this hypothesis, a high (millimolar) concentration of $\mathrm{H}_{2} \mathrm{O}_{2}$ has been reported to cause platelet aggregation (5). Lower (micromolar) concentrations of $\mathrm{H}_{2} \mathrm{O}_{2}$ diffusing from activated leukocytes may hemolyse red cells from patients with glucose-6-phosphate dehydrogenase deficiency (6) and may decrease platelet aggregation in response to ADP (7). Finally, Salin and McCord have observed that added SOD can protect both joint fluid from damage by phagocytosing granulocytes and the phago-

\footnotetext{
${ }^{1}$ Abbreviations used in this paper: ASA, acetylsalicylic acid; $\mathrm{H}_{2} \mathrm{O}_{2}$, hydrogen peroxide; KRP, Krebs-Ringer phosphate buffer; MDA, malonyldialdehyde; $\mathrm{O}_{2}^{-}$, superoxide anion; $\mathrm{OH} \cdot$, hydroxyl radical; $\mathrm{PGE}_{1}$, prostaglandin $\mathrm{E}_{1}$; $\mathrm{SOD}$, superoxide dismutase; TBA, thiobarbituric acid.
} 
TABLE I

Release of $\left[{ }^{14} \mathrm{C}\right]$ Serotonin and ${ }^{51} \mathrm{Cr}$ from Washed Platelets Incubated with Xanthine-Xanthine Oxidase

\begin{tabular}{|c|c|c|}
\hline Addition & $\begin{array}{c}{\left[{ }^{14} \mathrm{C}\right] \text { Serotonin }} \\
\text { released }\end{array}$ & ${ }^{{ }^{51} \mathrm{Cr}}$ \\
\hline
\end{tabular}

$\%$

None

Xanthine $(0.15 \mathrm{mM})$

Xanthine oxidase $(150 \mu \mathrm{g})$

Xanthine-xanthine oxidase

$5 \pm 2$

$7 \pm 3$

$9 \pm 3$

$6 \pm 2$

$68 \pm 4$

$-$

+ SOD $(50 \mu \mathrm{g} / \mathrm{ml})$

+ Catalase $(40 \mu \mathrm{g} / \mathrm{ml})$

$13 \pm 4$

$52 \pm 6$

$61 \pm 5$

$21 \pm 6$

$19 \pm 3$

$8 \pm 4$

+ Mannitol (1 mM)

$23 \pm 4$

Enzyme inhibitor mixtures in $0.9 \mathrm{ml} \mathrm{KRP}$ buffer were incubated at $37^{\circ} \mathrm{C}$ for $5 \mathrm{~min}$. Then $0.1 \mathrm{ml} \mathrm{KRP}$ containing $2.5 \times 10^{8}$ platelets that had been prelabeled with $\left[{ }^{14} \mathrm{C}\right]-$ serotonin or ${ }^{51} \mathrm{Cr}$ were rapidly added and incubated with constant agitation for an additional $5 \mathrm{~min}$. The reaction was stopped by making the samples $1 \mathrm{mM}$ in EDTA and placing them at ice bath temperature. Platelets were then collected onto $0.45-\mu \mathrm{m}$ Millipore filters under reduced pressure and retained $\left[{ }^{14} \mathrm{C}\right]$ serotonin determined by liquid scintillation counting and adsorbed ${ }^{51} \mathrm{Cr}$ determined in a Gamma counter. Values are mean \pm SEM for five experiments.

cytes themselves $(8,9)$. Their studies strongly suggest an oxidative mechanism of injury, probably mediated by $\mathrm{OH} \cdot$.

Since platelet exposure to oxidants or free radicals might influence subsequent hemostatic reactions, we have compared the effects of $\mathrm{O}_{2}^{-}, \mathrm{H}_{2} \mathrm{O}_{2}$, and $\mathrm{OH}$. on platelet function. The data demonstrate that enzymatic production of $\mathrm{O}_{2}^{-}$in suspensions of washed platelets by a mixture of xanthine and xanthine oxidase may promote platelet aggregation and release reactions and may represent a new and potentially important pathway to modulate platelet function.

\section{METHODS}

Xanthine, mannitol, xanthine oxidase (xanthine:oxygen oxidoreductase EC 1.2.3.2, $0.5 \mathrm{U} / \mathrm{mg}$ ), epinephrine bitartrate, ADP, $N^{6}, O^{2}$-dibutyryl adenosine $3^{\prime}, 5^{\prime}$-cyclic monophosphoric acid (dibutyryl cyclic AMP) were obtained from Sigma Chemical Co., St. Louis, Mo. Superoxide dismutase (superoxide: superoxide oxidoreductase EC 1. 15. 1.1., [SOD]) was obtained from Truett Labs., Dallas, Tex. and had a sp act of $3,000 \mathrm{U} / \mathrm{mg}$. Catalase $(30,000 \mathrm{U} / \mathrm{mg})$ and cytochrome $c$ were purchased from Boehringer Mannheim Biochemicals, Indianapolis, Ind. Acetylsalicylic acid (ASA) and $1,1,3,3$, tetraethoxypropane were purchased from $K \& K$ Laboratories, Inc., Plainview, N. Y. Prostaglandin $\mathrm{E}_{1}\left(\mathrm{PGE}_{1}\right)$ was a gift of Dr. John Pike, The Upjohn Co., Kalamazoo, Mich. Human thrombin $(2,100 \mathrm{NIH} \mathrm{U} / \mathrm{mg})$ was a gift of Dr. Robert Rosenberg, Sidney Farber Cancer Center, Boston, Mass. $\left[2{ }^{14} \mathrm{C}\right] 5$-hydroxytryptamine binoxalate $\left(\left[{ }^{14} \mathrm{C}\right]\right.$ serotonin $50 \mathrm{mCi} / \mathrm{mmol})$ and $\mathrm{Na}^{51} \mathrm{Cr} \mathrm{O}_{4}=\left({ }^{51} \mathrm{Cr}, 250 \mathrm{Ci} / \mathrm{g}\right)$ were purchased from New England Nuclear, Boston, Mass.

Preparation of platelets. Blood obtained from normal human volunteers with a two-syringe technique was anti- coagulated with $1 \mathrm{ml}$ acid citrate dextrose solution (NIH Formula A) for each $5 \mathrm{ml}$ of blood and centrifuged at $80 \mathrm{~g}$ for $10 \mathrm{~min}$ at room temperature. The platelet-rich plasma was aspirated and incubated with $2 \mu \mathrm{Ci} / \mathrm{ml}\left[{ }^{14} \mathrm{C}\right]$ serotonin for $30 \mathrm{~min}$ at $37^{\circ} \mathrm{C}$. Under these conditions, $85 \pm 7 \%$ of the $\left[{ }^{14} \mathrm{C}\right]$ serotonin was taken up by the platelets. They were then centrifuged at $500 \mathrm{~g}$ for $10 \mathrm{~min}$ and the platelet pellet resuspended in a modified Krebs-Ringer phosphate buffer (KRP) made up of $0.15 \mathrm{M} \mathrm{NaCl}, 0.005 \mathrm{M} \mathrm{KCl}$, $0.001 \mathrm{M} \mathrm{MgCl}, 0.001 \mathrm{M} \mathrm{CaCl}_{2}, 0.01 \mathrm{M} \mathrm{PO}_{4}=, \mathrm{pH}$ 7.2. To label platelets with ${ }^{51} \mathrm{Cr}$, the pellet was suspended in 0.5-1 $\mathrm{ml}$ of platelet-poor plasma containing $100 \mu \mathrm{Ci}^{51} \mathrm{Cr}$ and then incubated at $37^{\circ} \mathrm{C}$ for $30 \mathrm{~min}$. The platelets were then diluted with 5-10 ml plasma, recentrifuged at $500 \mathrm{~g}$ for 10 min, and then suspended in KRP. An average of $8 \%$ of the ${ }^{{ }^{11} \mathrm{Cr}}$ was taken up by the platelets. With the procedures outlined above, $64 \pm 4 \%(\bar{x} \pm \mathrm{SEM})$ of the total platelets was harvested with an average of one leukocyte and five erythrocytes $/ 1,000$ platelets. There was no visible aggregation and rare aggregates of two to five platelets were seen under phase-contrast microscope examination.

Measurement of $\mathrm{O}_{2}^{-}$production. Before use, xanthine oxidase, SOD, and catalase were dialyzed against KRP buffer. $\mathrm{O}_{2}{ }^{-}$was generated by incubating $0.15 \mathrm{mM}$ xanthine with varying concentrations of xanthine oxidase. The flux of $\mathrm{O}_{2}^{-}$was quantitated by measuring the rate at which $\mathrm{O}_{2}^{-}$donates an electron to reduce ferricytochrome $c$ as described by McCord and Fridovich. (10), Specificity of the reduction reaction was measured by including control mixtures containing an excess of the $\mathrm{O}_{2}^{-}$scavenger SOD. This enzyme competitively inhibits $\mathrm{O}_{2}^{-}$-dependent reduction of cytochrome $c(10)$. Calculations were based on an є $550 \mathrm{~nm}$ reduced-oxidized for cytochrome $c$ of $15,500 \mathrm{M}^{-1}$ $\mathrm{cm}^{-1}$ (11). The reaction was followed in a Gilford model 2400 spectrophotometer (Gilford Instruments Laboratories Inc., Oberlin, Ohio) that had been adjusted for maximal absorbance at $550 \mathrm{~nm}$ with dithionite-reduced cytochrome $c$. Catalase activity was measured from the rate of change in absorbance at $260 \mathrm{~nm}$, after the addition of measured quantities of $\mathrm{H}_{2} \mathrm{O}_{2}$ (12).

Measurement of Malonyldialdehyde. Malonyldialdehyde (MDA) was measured by the thiobarbituric acid reaction (13). $1 \mathrm{ml}$ of $7 \%$ perchloric acid was added to $1 \mathrm{ml}$ of KRP buffer containing $2 \times 10^{9}$ platelets, followed by $1 \mathrm{ml}$ $0.5 \%$ thiobarbituric acid (TBA). The mixtures were then placed in a boiling water bath for $10 \mathrm{~min}$, centrifuged at $500 \mathrm{~g}$ for $10 \mathrm{~min}$, the supernate aspirated, and its absorbance at $548 \mathrm{~nm}$ determined. If necessary, turbidity was removed by extraction with one part chloroform for three parts of reaction mixture. A standard curve was constructed using authentic MDA produced by overnight hydrolysis of 1,1,3,3,-tetraethoxypropane in $1 \mathrm{~N} \mathrm{HCl}$ (14). The yield of MDA was estimated using the $\epsilon$ of 1.45 $\times 10^{5} \mathrm{M}^{-1} \mathrm{~cm}^{-1}$ and found to be stoichiometric.

Measurement of platelet aggregation and release. Platelets were added to $0.5-1 \mathrm{ml} \mathrm{KRP}$ buffer containing xanthine, xanthine oxidase, and, where indicated, SOD, catalase, or mannitol. For some experiments, platelets were preincubated for $15 \mathrm{~min}$ with ASA, indomethacin, dibutyryl cyclic AMP, or $\mathrm{PGE}_{1}$ before admixture with xanthine and xanthine oxidase. The reaction was stopped by adding $1 \mathrm{ml}$ ice-cold $2 \mathrm{mM}$ EDTA in $0.15 \mathrm{M} \mathrm{NaCl}$ and placing the tubes in a melting ice bath. Platelets were then collected by filtration under reduced pressure onto $0.45-\mu \mathrm{m}$ Millipore filters (HAWP-25 Millipore Corp., Bedford, Mass.) that had been presoaked in $0.2 \%$ bovine serum albumin as described by Tollefson et al. (15). The filters were then washed with $10 \mathrm{ml} \mathrm{KRP}$, dried at $80^{\circ} \mathrm{C}$ in a circulating air oven, and placed in $10 \mathrm{ml}$ scintillation fluid. Each liter of fluid contained $340 \mathrm{ml}$ Triton X-100, $11 \mathrm{~g}$ 


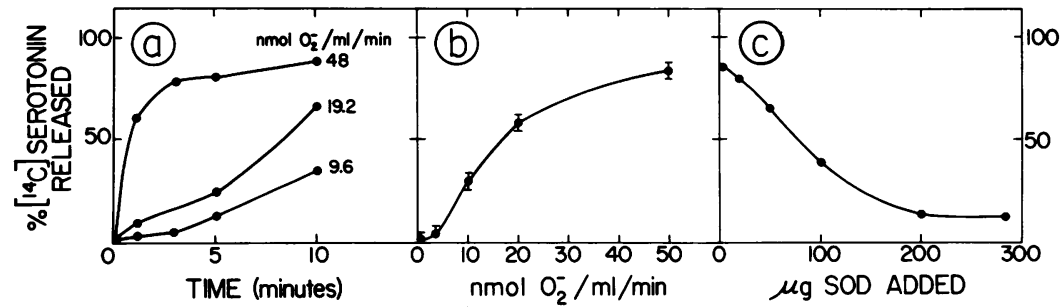

FIGURE $1 \mathrm{O}_{2}^{-}$induced release of $\left[{ }^{14} \mathrm{C}\right]$ serotonin and its inhibition by SOD are depicted. The flux of $\mathrm{O}_{2}^{-}$produced by various concentrations of xanthine oxidase was measured by the technique of McCord and Fridovich (10). In the left hand panel, $(1 a)$ the effect of incubation with $\mathrm{O}_{2}^{-}$for varying time periods is shown. The middle panel ( $\left.1 b\right)$ depicts the effect of varying the flux of $\mathrm{O}_{2}{ }^{-}$between 5 and $50 \mathrm{nmol} \mathrm{O}_{2}^{-} / \mathrm{ml}$ per $\min .2 .5 \times 10^{8}$ platelets were exposed to this flux for $10 \mathrm{~min}$. In the right hand panel, (1c) $2.5 \times 10^{8}$ platelets were exposed to $48 \mathrm{nmol} \mathrm{O}_{2}^{-}$and varying concentrations of SOD for $10 \mathrm{~min}$. In all these experiments platelets were prelabeled with $\left[{ }^{14} \mathrm{C}\right]$ serotonin and incubation carried out in KRP containing $0.15 \mathrm{mM}$ xanthine and varying amounts of xanthine oxidase. The quantity of intraplatelet $\left[{ }^{14} \mathrm{C}\right]$ serotonin was measured by collection of the platelets onto $0.45-\mu \mathrm{M}$ Millipore filters. The middle panel represents mean \pm SEM for three experiments.

$p$-bis(O-methylstyryl)benzene, $7 \mathrm{~g}$ PPO, and $660 \mathrm{ml}$ toluene. Samples were counted in an Isocap 300 liquid scintillation counter (Searle Analytic Inc., Des Plaines, Ill.) using the channels ratio method for quench correction. The quantity of ${ }^{51} \mathrm{Cr}$ adsorbed onto the filter disks was determined in a Baird Atomic Gamma Counter (Baird Atomic, Inc., Bedford, Mass.). Platelet aggregation was studied with a Chrono-Log aggregometer (Chrono-Log Corp., Broomall, $\mathrm{Pa}$.) by adding $0.1 \mathrm{ml}$ platelet suspension to $0.4 \mathrm{ml} \mathrm{KRP}$ buffer containing xanthine and xanthine oxidase and continuously recording the percentage of light transmission for $5 \mathrm{~min}(16)$.

\section{RESULTS}

Platelet release and aggregation. As shown in Table I, the addition of washed platelets to KRP buffer that contained $0.15 \mathrm{mM}$ xanthine and 150 $\mu \mathrm{g} / \mathrm{ml}$ xanthine oxidase caused them to release $\left[{ }^{14} \mathrm{C}\right]-$ serotonin. Induction of the release reaction was prevented by omitting the xanthine or xanthine oxidase or by inactivating the enzyme by boiling for $30 \mathrm{~s}$. Release was also prevented by including the $\mathrm{O}_{2}{ }^{-}$ scavenger SOD in the incubation mixture before the addition of platelets. Addition of SOD inactivated by autoclaving at $124^{\circ} \mathrm{C}$ for $10 \mathrm{~min}$ did not inhibit release of $\left[{ }^{14} \mathrm{C}\right]$ serotonin by the xanthine-xanthine oxidase mixture. Addition of $40 \mu \mathrm{g} / \mathrm{ml}$ catalase or 1 $\mathrm{mM}$ mannitol, a free radical scavenger, to the xanthinexanthine oxidase mixture did not inhibit the release reaction.

As shown in Fig. 1, the quantity of $\left[{ }^{14} \mathrm{C}\right]$ serotonin released during incubation with xanthine-xanthine oxidase was influenced by the flux of $\mathrm{O}_{2}{ }^{-}$generated and the duration of exposure to $\mathrm{O}_{2}{ }^{-}$. After incubation of platelets with a flux of $48 \mathrm{nmol} \mathrm{O}_{2}{ }^{-} / \mathrm{min}$ per $\mathrm{ml}$, there was maximal release of $\left[{ }^{14} \mathrm{C}\right]$ serotonin within $3 \mathrm{~min}$ (Fig. 1a). With lower fluxes of $\mathrm{O}_{2}^{-}$, induction of release was delayed and a smaller percentage of the available $\left[{ }^{14} \mathrm{C}\right]$ serotonin was released. In subsequent experiments (Fig. $1 b$ ), incuba- tion was carried out for $10 \mathrm{~min}$ and the flux of $\mathrm{O}_{2}{ }^{-}$ varied. Under these conditions, detectable release required a flux of $10 \mathrm{nmol} \mathrm{O}_{2}^{-} / \mathrm{min}$ while maximal release occurred with a flux greater than $25 \mathrm{nmol}$ $\mathrm{O}_{2}-/$ min. The quantity of $\left[{ }^{14} \mathrm{C}\right]$ serotonin released by exposure to $25 \mathrm{nmol} / \mathrm{min} \mathrm{O}_{2}^{-}$was inhibited by the addition of increasing quantities of SOD and complete inhibition was achieved with $200 \mu \mathrm{g} / \mathrm{ml}$ SOD.

Washed platelets also aggregated when stirred in a cuvette containing xanthine-xanthine oxidase (Fig. 2 ). The aggregation pattern was monophasic and

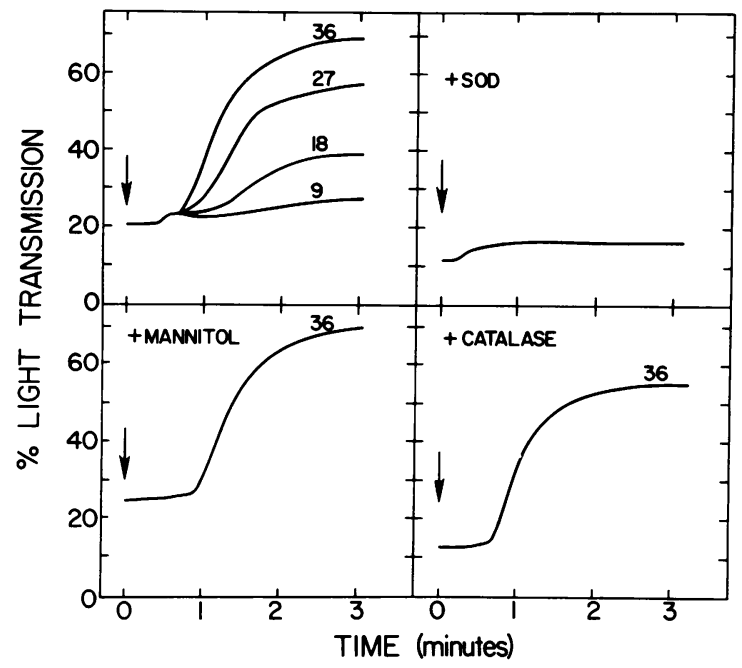

FIGURE 2 Aggregation of platelets by xanthine-xanthine oxidase mixtures is depicted. $1.5 \times 10^{8}$ platelets were suspended in $0.5 \mathrm{ml} \mathrm{KRP} \mathrm{buffer} \mathrm{containing} 0.15 \mathrm{mM}$ xanthine and where indicated either $200 \mu \mathrm{g} / \mathrm{ml}$ SOD, $1 \mathrm{mM}$ mannitol, or $40 \mu \mathrm{g} / \mathrm{ml}$ catalase. At the arrow measured quantities of xanthine oxidase in $10 \mu \mathrm{l} \mathrm{KRP} \mathrm{buffer}$ were added and the light transmission continuously recorded as the platelet suspensions were stirred in a Chrono-Log Aggregometer. The numbers above each tracing represent the flux of $\mathrm{O}_{2}^{-}$ produced in nanomoles per minute per milliliter. 


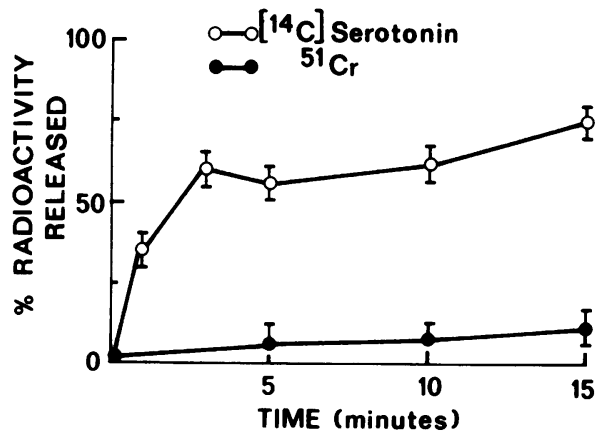

FIgURE 3 The release of $\left[{ }^{14} \mathrm{C}\right]$ serotonin from platelets is compared to the release of ${ }^{51} \mathrm{Cr}$ after incubation with 0.15 $\mathrm{mM}$ xanthine and $150 \mu \mathrm{g} / \mathrm{ml}$ xanthine oxidase. This concentration of enzyme produced a flux of $42 \mathrm{nmol} \mathrm{O}_{2}^{-} / \mathrm{min}$ per $\mathrm{ml}$ incubation mixture. Incubations containing platelets labeled with either ${ }^{51} \mathrm{Cr}$ or $\left[{ }^{14} \mathrm{C}\right]$ serotonin were run simultaneously. At the indicated times $0.1-\mathrm{ml}$ portions were removed and intraplatelet $\left[{ }^{14} \mathrm{C}\right]$ serotonin or ${ }^{31} \mathrm{Cr}$ measured.

the extent of aggregation was dependent on the flux of $\mathrm{O}_{2}^{-}$generated and the duration of exposure. The pattern of inhibition by enzymes and free radical scavengers was similar to that observed when studying the release of $\left[{ }^{14} \mathrm{C}\right]$ serotonin (Fig. 2). $200 \mu \mathrm{g} / \mathrm{ml}$ of SOD prevented aggregation, and $1 \mathrm{mM}$ mannitol or $40 \mu \mathrm{g} / \mathrm{ml}$ catalase had no effect. Although SOD could prevent aggregation by xanthine-xanthine oxidase, it had no effect on aggregation induced by collagen. (not shown).

Release of intraplatelet ${ }^{51} \mathrm{Cr}$. In parallel experiments, platelets labeled with ${ }^{51} \mathrm{Cr}$ rather than $\left[{ }^{14} \mathrm{C}\right]-$ serotonin were added to KRP buffer containing xanthine-xanthine oxidase. As shown in Fig. 3, the efflux of ${ }^{51} \mathrm{Cr}$, which is bound to platelet cytosol proteins, occurred much slower than the discharge of $\left[{ }^{14} \mathrm{C}\right]$ serotonin which is localized in platelet dense granules. After a 15-min exposure to xanthine-xanthine oxidase, there was release of $85 \%$ of the available intraplatelet $\left[{ }^{14} \mathrm{C}\right]$ serotonin while only $15 \%$ of the total ${ }^{51} \mathrm{Cr}$ had leaked from the platelet. In addition, the leakage of ${ }^{51} \mathrm{Cr}$ was not inhibited by SOD or mannitol but was completely inhibited by the addition of 40 $\mu \mathrm{g} / \mathrm{ml}$ catalase to the incubation media. (Table I).

Inhibition of platelet release. Since exposure to $\mathrm{O}_{2}{ }^{-}$specifically induced platelet aggregation and released $\left[{ }^{14} \mathrm{C}\right]$ serotonin, the effect of agents which block these events was studied. The reagents chosen were ASA and indomethacin which block prostaglandin biosynthesis, and dibutyryl cyclic AMP and $\mathrm{PGE}_{1}$ which raise the intraplatelet content of cyclic AMP. Preincubation of platelets with $1 \mu \mathrm{M} \mathrm{PGE}_{1}$ or $1 \mathrm{mM}$ dibutyryl cyclic AMP for $15 \mathrm{~min}$ at $37^{\circ} \mathrm{C}$ prevented subsequent release of $\left[{ }^{14} \mathrm{C}\right]$ serotonin by the $\mathrm{O}_{2}{ }^{-}$generating system. (Table II) In contrast, prior incubation with $1 \mathrm{mM}$ ASA or $1 \mu \mathrm{M}$ indomethacin had no effect on the release reaction. $\mathrm{O}_{2}{ }^{-}$-induced release was also inhibited by the addition of $1 \mathrm{mM}$ EDTA to the KRP buffer.

The concentrations of inhibitors used in these studies did not interfere with the enzymatic generation of $\mathrm{O}_{2}^{-}$using the stoichiometric reduction of ferrocytochrome $c$ as the assay system. The flux of $\mathrm{O}_{2}^{-}$ generated was unaffected by omission or chelation of divalent cations in the KRP buffer, or by the presence of $1 \mathrm{mM}$ ASA, $1 \mu \mathrm{M}$ indomethacin, $1 \mathrm{mM}$ dibutyryl cyclic AMP, or $1 \mu \mathrm{m}$ PGE $_{1}$.

Production of MDA. As shown in Table III, incubation of platelets with sufficient xanthine-xanthine oxidase to release intraplatelet $\left[{ }^{14} \mathrm{C}\right]$ serotonin did not stimulate the production of MDA. Since ferric chloride has been reported to increase MDA formation by subcellular organelles exposed to free radicals, it was added to the platelet suspensions along with xanthine-xanthine oxidase. As shown in Table IV, concentrations of ferric chloride ranging from $1 \mu \mathrm{M}$ to $1 \mathrm{mM}$ progressively increased the amount of MDA detected by the TBA reaction. However, the same amount of TBA-reactive material was obtained without xanthine-xanthine oxidase in the incubation, suggesting that the observed effect was independent of the superoxide-generating system.

Effects of thrombin on release and MDA production. For comparison, we determined the effects of purified human thrombin on platelet release and MDA formation. Incubation with $0.5 \mathrm{U} / \mathrm{ml}$ thrombin released $65 \pm 8 \%$ of the intraplatelet $\left[{ }^{14} \mathrm{C}\right]$ serotonin while producing $5.1 \pm 0.3 \mathrm{nmol} \mathrm{MDA} / 10^{9}$ platelets $(x \pm \mathrm{SEM})$. Preincubation with ASA or indomethacin reduced platelet production of MDA by $93 \%$ but did not significantly impair release of $\left[{ }^{14} \mathrm{C}\right]$ serotonin. In con-

TABLE II

Inhibition of $\mathrm{O}_{2}-$-Induced Release

\begin{tabular}{lc}
\hline \multicolumn{1}{c}{ Addition } & {$\left[{ }^{14} \mathrm{C}\right]$ Serotonin released } \\
\hline & $\%$ \\
None & $2 \pm 1$ \\
Xanthine-xanthine oxidase & $71 \pm 3$ \\
PGE $_{1}(1 \mu \mathrm{M})$ & $7 \pm 1$ \\
Dibutyryl cyclic AMP $(1 \mathrm{mM})$ & $6 \pm 2$ \\
ASA (1 mM) & $72 \pm 3$ \\
Indomethacin $(1 \mu \mathrm{M})$ & $74 \pm 2$ \\
EDTA (1 mM) & $4 \pm 3$ \\
\hline
\end{tabular}

$2.5 \times 10^{8}$ platelets in $0.1 \mathrm{ml} \mathrm{KRP}$ were incubated with the indicated concentration of $\mathrm{PGE}_{1}, \mathrm{ASA}$, indomethacin, or dibutyrylcyclic AMP for $15 \mathrm{~min}$ at $37^{\circ} \mathrm{C}$. Then $0.9 \mathrm{ml} \mathrm{KRP}$ containing $0.15 \mathrm{mM}$ xanthine and $0.15 \mathrm{U} / \mathrm{ml}$ xanthine oxidase that had been incubated together for $5 \mathrm{~min}$ at $37^{\circ} \mathrm{C}$ was added. This produced a flux of $38 \mathrm{nmol} \mathrm{O}_{2}^{-} / \mathrm{min}$. At the end of $5 \mathrm{~min}$, the samples were made $1 \mathrm{mM}$ in EDTA, chilled in an ice bath, and intraplatelet $\left[{ }^{14} \mathrm{C}\right]$ serotonin determined by collection of platelets onto $0.45-\mu \mathrm{m}$ Millipore filters. Values are \pm SEM for four experiments. 
trast, exposure to $1 \mu \mathrm{M} \mathrm{PGE}_{1}$ inhibited the release of $\left[{ }^{14} \mathrm{C}\right]$ serotonin by $80 \%$ while reducing MDA production by only $20 \%$. These results suggest that release induced by thrombin can also be dissociated from MDA formation and can occur in the presence of cyclo-oxygenase inhibitors like ASA and indomethacin.

The combined effect of thrombin and $\mathrm{O}_{2}{ }^{-}$on platelet release. The effect of prior exposure to a low flux of $\mathrm{O}_{2}^{-}$on the subsequent release reaction induced by incubation with thrombin was then evaluated. The relationship between thrombin concentration and the release of $\left[{ }^{14} \mathrm{C}\right]$ serotonin for platelets suspended in KRP buffer is depicted in Fig. 4. As noted, detectable release required the addition of at least $0.02 \mathrm{U} / \mathrm{ml}$ thrombin to the platelet suspensions and maximal release required over $0.1 \mathrm{U} / \mathrm{ml}$.

To study the combined effects of thrombin and $\mathrm{O}_{2}{ }^{-}$, platelets were first incubated with $20 \mu \mathrm{g} / \mathrm{ml}$ xanthine oxidase and $0.15 \mathrm{mM}$ xanthine for $5 \mathrm{~min}$. This concentration of xanthine oxidase was insufficient to induce release. After a 5-min exposure to $\mathrm{O}_{2}{ }^{-}$, the addition of $0.002 \mathrm{U} / \mathrm{ml}$ thrombin rapidly induced maximal release of $\left[{ }^{14} \mathrm{C}\right]$ serotonin. (Fig. 5) Incubation with heated xanthine oxidase followed by the addition of identical thrombin concentrations did not induce platelet release of $\left[{ }^{14} \mathrm{C}\right]$ serotonin. Furthermore, the addition of SOD to the xanthine-xanthine oxidase mixture prevented subsequent release by low doses of thrombin (not shown). Catalase and mannitol had no

\section{TABLE III}

Platelet MDA Production after Incubation with Xanthine-Xanthine Oxidase

\begin{tabular}{lcc}
\hline \multicolumn{1}{c}{$\begin{array}{c}\text { Incubation } \\
\text { mixture }\end{array}$} & $\begin{array}{c}\text { nmol MDA } 10^{\circ} \\
\text { Platelets }\end{array}$ & $\begin{array}{c}\left.{ }^{14} \mathrm{C}\right] \text { Serotonin } \\
\text { release }\end{array}$ \\
\hline $\begin{array}{l}\text { Buffer } \\
\text { Xanthine }(0.15 \mathrm{mM})\end{array}$ & $0.20 \pm 0.02$ & $5 \pm 3$ \\
$\begin{array}{l}\text { Xanthine-xanthine oxidase } \\
(80 \mu \mathrm{g} / \mathrm{ml})\end{array}$ & $0.21 \pm 0.03$ & $6 \pm 2$ \\
$\begin{array}{l}\text { Xanthine-xanthine oxidase } \\
(150 \mu \mathrm{g} / \mathrm{ml})\end{array}$ & $0.24 \pm 0.03$ & $22 \pm 6$ \\
$\begin{array}{l}\text { Xanthine-xanthine oxidase } \\
(180 \mu \mathrm{g} / \mathrm{ml})\end{array}$ & $0.24 \pm 0.03$ & $49 \pm 7$ \\
\hline
\end{tabular}

$2.5 \times 10^{9}$ platelets were added to the xanthine-xanthine oxidase mixtures as previously described. The flux of $\mathrm{O}_{2}{ }^{-}$ varied from 18 to $78 \mathrm{nmol} / \mathrm{min}$. After a 5 -min incubation at $37^{\circ} \mathrm{C}$, an aliquot was removed for determination of released $\left[{ }^{[14} \mathrm{C}\right]$ serotonin. The remainder of the incubation was mixed with $1 \mathrm{ml} 7 \%$ perchloric acid, followed by $1 \mathrm{ml} 0.5 \%$ TBA and heated in boiling water for $10 \mathrm{~min}$. The absorbance at $548 \mathrm{~nm}$ was determined and compared to authentic MDA standards. Values are mean \pm SEM for five experiments.
TABLE IV

Effect of Ferric Chloride on Platelet MDA Production

\begin{tabular}{|c|c|c|}
\hline \multirow[b]{2}{*}{$\mathrm{FeCl}_{3}$ added } & \multicolumn{2}{|c|}{$\begin{array}{l}\text { Xanthine-xanthine } \\
\text { oxidase }\end{array}$} \\
\hline & Without & With \\
\hline mol/liter & \multicolumn{2}{|c|}{ nmol MDA $/ 10^{9}$ platelet } \\
\hline None & 0.50 & 0.55 \\
\hline $1 \times 10^{-6}$ & 0.64 & 0.65 \\
\hline $1 \times 10^{-5}$ & 0.83 & 0.76 \\
\hline $1 \times 10^{-4}$ & 1.21 & 1.25 \\
\hline $1 \times 10^{-3}$ & 3.11 & 3.07 \\
\hline
\end{tabular}

For these experiments, $2.5 \times 10^{9}$ platelets were added to KRP buffer containing the indicated concentration of ferric chloride alone or along with $0.15 \mathrm{mM}$ xanthine and $140 \mu \mathrm{g} / \mathrm{ml}$ xanthine oxidase and incubated for $5 \mathrm{~min}$ at $37^{\circ} \mathrm{C}$. This produced a flux of $45 \mathrm{nmol} \mathrm{O}_{2}{ }^{-} / \mathrm{min}$. The samples were then analyzed for MDA content as previously described.

effect. Thus, prior exposure to this low flux of $\mathrm{O}_{2}^{-}$ lowered the threshold for thrombin 10-fold. While these observations could be repeated with different platelet preparations, the precise concentrations of xanthine oxidase and thrombin needed to produce this synergistic effect varied slightly with platelets obtained from different normal donors.

\section{DISCUSSION}

The data presented here document that incubation of platelets with xanthine and xanthine oxidase can induce platelet aggregation and release of $\left[{ }^{14} \mathrm{C}\right]-$ serotonin. The inhibition of aggregation and release by the $\mathrm{O}_{2}{ }^{-}$scavenger $\mathrm{SOD}$, but not by catalase or mannitol, suggests that $\mathrm{O}_{2}^{-}$is the active species involved and shows that $\mathrm{O}_{2}{ }^{-}$can directly affect platelet function. Furthermore, the observation that $\left[{ }^{14} \mathrm{C}\right]-$ serotonin is released under conditions in which the platelet retains ${ }^{51} \mathrm{Cr}$ suggests that release and aggre-

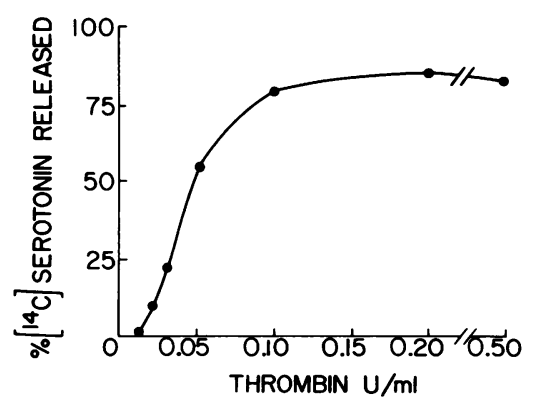

FIgURE 4 Release of $\left[{ }^{14} \mathrm{C}\right]$ serotonin after incubation with various concentrations of thrombin is depicted. Incubations were carried out for $5 \mathrm{~min}$ at $37^{\circ} \mathrm{C}$ and platelets collected onto Millipore filters to determine intraplatelet radioactivity. 


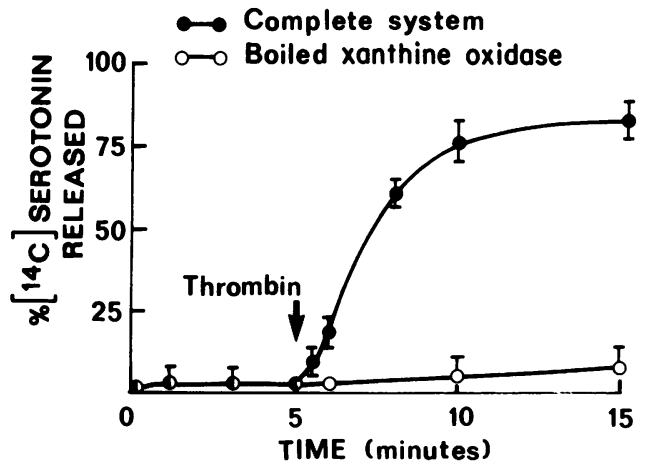

FIGURE 5 The combined effect of incubation with $\mathrm{O}_{2}{ }^{-}$ and thrombin is depicted. Platelets were initially exposed to $20 \mu \mathrm{g} / \mathrm{ml}$ xanthine oxidase for $5 \mathrm{~min}$. This produced a flux of $10 \mathrm{nmol} \mathrm{O}_{2}{ }^{-} / \mathrm{min}$ per $\mathrm{ml}$. Then $0.002 \mathrm{U} / \mathrm{ml}$ thrombin was added and the incubation continued for $5 \mathrm{~min}$. Control incubations contained xanthine oxidase that had been heated in boiling water for $30 \mathrm{~s}$.

gation are not the result of generalized platelet injury or lysis.

Interpretation of the patterns of isotope release after platelet exposure to the xanthine-xanthine oxidase mixture is complicated by the observation that, after prolonged incubation, there is also some leakage of ${ }^{51} \mathrm{Cr}$ from the platelet. Since this is prevented by catalase and not by SOD, it is probably due to $\mathrm{H}_{2} \mathrm{O}_{2}$ produced during the incubation. $\mathrm{H}_{2} \mathrm{O}_{2}$, which arises from the spontaneous dismutation of $\mathrm{O}_{2}{ }^{-}$, or by the direct two-electron reduction of oxygen, could directly damage the platelet membrane and allow leakage of ${ }^{51} \mathrm{Cr}$. Alternatively, the $\mathrm{H}_{2} \mathrm{O}_{2}$ produced might react with additional $\mathrm{O}_{2}^{-}$via the Haber-Weiss pathway to produce the $\mathrm{OH}$ - radical which could then attack the platelet membrane (2). Although $\mathrm{OH}$ - has been implicated in a number of different types of tissue damage $(8,9)$, it does not appear to play a major role in the platelet reactions studied here, as addition of the $\mathrm{OH}$ - scavenger mannitol did not inhibit the release of $\left[{ }^{14} \mathrm{C}\right]$ serotonin or the leakage of ${ }^{51} \mathrm{Cr}$.

Platelet aggregation and release induced by a variety of stimuli are modulated, by the intraplatelet content of cyclic AMP and by the production of prostaglandin endoperoxide derivatives such as thromboxane $A_{2}$ (17-19). In our experiments, release induced by $\mathrm{O}_{2}^{-}$was inhibited by agents which increased intracellular cyclic AMP, such as dibutyryl cyclic AMP or $P G_{1}$, but was not inhibited by the prostaglandin synthetase inhibitors ASA or indomethacin. In addition, MDA production did not increase after incubation with sufficient xanthine-xanthine oxidase to produce platelet aggregation and release.

It was anticipated that MDA might also arise from direct peroxidation of platelet membrane lipids after exposure to the $\mathrm{O}_{2}{ }^{-}$and $\mathrm{OH} \cdot$ generated during the oxidation of xanthine. For example, Fong et al. (20) reported that liver lysosomes leaked hydrolytic enzymes after incubation with xanthine xanthine oxidase. Damage to these lysosomes was accompanied by lipid peroxidation as measured by the production of MDA, and optimal MDA reactivity required the presence of ADP and $\mathrm{FeCl}_{3}$. Kellogg and Fridovich have recently pointed out that color intensity in the TBA test is influenced by the presence of iron salts (21). Thus, increased color in the presence of iron may not represent a true increase in lipid peroxidation but an increase in color yield from a fixed amount of lipid peroxide. In our studies, the increase in apparent MDA formation induced by incubation of platelets with ferric chloride occurred without the addition of the enzyme mixture generating $\mathrm{O}_{2}{ }^{-}$suggesting a direct effect of the iron salt.

The fact that release occurred in platelets pretreated with ASA and indomethacin is additional evidence that the prostaglandin endoperoxide pathway is not utilized. It is possible that we did not detect small amounts of lipid peroxidation or prostaglandin production since we did not directly measure these compounds. Measurement of conjugated diene formation or iodimetric titration of lipid hydroperoxides and radioimmunoassay of prostaglandins (22-24) would be of interest. However, the most logical inference of our experiments is that neither of the two possible pathways for MDA production were stimulated by $\mathrm{O}_{2}^{-}$or any of its secondary products.

Since $\mathrm{O}_{2}^{-}$-induced release is inhibited by increasing the intraplatelet level of cyclic AMP, it is possible the $\mathrm{O}_{2}^{-}$might exert its effect via the adenyl cyclase system. Thrombin, and other aggregating agents, clearly inhibit adenyl cyclase activity (25-27). The fact that thrombin also synergizes with $\mathrm{O}_{2}^{-}$to produce aggregation and release suggests that the two stimuli may act on similar or closely related membrane sites. Such synergistic effects have been observed when platelets are exposed to other combinations of aggregating agents $(28,29)$.

The physiological significance of the $\mathrm{O}_{2}{ }^{-}$platelet interaction has not been completely defined by these experiments. All aerobic cells generate $\mathrm{O}_{2}{ }^{-}$and contain both mitochondrial and cytoplasmic forms of SOD to scavenge any $\mathrm{O}_{2}^{-}$that is generated (1). Since SOD is an intracellular enzyme, it will not prevent external $\mathrm{O}_{2}{ }^{-}$from reaching cell membranes. There is increasing evidence that $\mathrm{O}_{2}^{-}$which may be produced at membrane sites by pyridine nucleotide-dependent oxidase enzymes, diffuses from activated leukocytes and could potentially reach other blood cells $(3,30)$. The flux produced by activated granulocytes is within the range that potentiated platelet aggregation and release in our experimental system (3). The quantity would not be high enough to directly induce aggregation and release. It is not known if this concentra- 
tion of $\mathrm{O}_{2}^{-}$is ever achieved in the microcirculation. However, it is possible that this amount of $\mathrm{O}_{2}^{-}$ could be generated in areas of vessel injury or inflammation in which granulocytes accumulate.

$\mathrm{O}_{2}{ }^{-}$may be useful in the study of platelet aggregation or release since its effect on the platelet is similar to high concentrations of thrombin, in at least one respect-it will stimulate release in the presence of prostaglandin synthetase inhibitors. Whether $\mathrm{O}_{2}{ }^{-}$ induces aggregation and release by the oxidation or reduction of multiple membrane sites by a more selective effect on membrane-associated enzymes, or in other ways, is a useful project for future studies.

\section{ACKNOWLEDGMENT}

The authors would like to thank Doctors Harvey Cohen and $H$. Franklin Bunn for their advice and encouragement and for reviewing the manuscript, and Vera Martin for her excellent technical assistance.

This work was supported by NIH grants HL 17513 and 5 SO1 RR05489-13.

\section{REFERENCES}

1. Fridovich, I. 1974. Superoxide dismutases. Advan. Enzymol. Relat. Areas Mol. Biol. 41: 35-57.

2. Haber, F., and J. Weiss. 1934. The catalytic decomposition of hydrogen by iron salts. Proc. Roy. Soc. Ser. A. 147: 332-351.

3. Babior, B. M., R. S. Kipnes, and J. T. Curnutte. 1973. Biological defense mechanisms. The production by leukocytes of superoxide, a potential bactericidal agent. J. Clin. Invest. 52: 741-744.

4. Root, R. K., J. Metcalf, N. Oshino, and B. Chance. 1975. $\mathrm{H}_{2} \mathrm{O}_{2}$ release from human granulocytes during phagocytosis. I. Documentation, quantitation, and some regulating factors. J. Clin. Invest. 55: 945-955.

5. Canoso, R. T., R. Rodvien, K. Scoon, and P. H. Levine. 1974. Hydrogen peroxide and platelet function. Blood. 43: 645-656.

6. Baehner, R. L., D. G. Nathan, and W. B. Castle. 1971. Oxidant injury of Caucasian glucose-6-phosphate dehydrogenase-deficient red blood cells by phagocytosing leukocytes during infection. J. Clin. Invest. 50: 2466-2473.

7. Levine, P. H., R. S. Weinger, J. Simon, K. L. Scoon, and N. I. Krinsky. 1976. Leukocyte-platelet interaction. Release of hydrogen peroxide by granulocytes as a modulator of platelet reactions. J. Clin. Invest. 57: 955-963.

8. McCord, J. M. 1974. Free radicals and inflammation: protection of synovial fluid by superoxide dismutase. Science (Wash. D. C.). 185: 529-531.

9. Salin, M. L., and J. M. McCord. 1975. Free radicals and inflammation. Protection of phagocytosing leukocytes by superoxide dismutase. J. Clin. Invest. 56: 13191323.

10. McCord, J. M., and I. Fridovich. 1969. Superoxide dismutase. An enzymic function for erythrocuprein (hemocuprein). J. Biol. Chem. 244: 6049-6055.

11. Margoliash, E., and N. Frohwirt. 1959. Spectrum of horse-heart cytochrome $c$. Biochem. J. 71: 570-572.

12. Sigma Chemical Company. Biochemical and organic compounds for research. April 1976 edition (catalog). Sigma Chemical Co. St. Louis, Mo. 123.
13. Placer, Z. A., L. L. Cushman, and B. C. Johnson. 1966. Estimation of product of lipid peroxidation (malonyl dialdehyde) in biochemical systems. Anal. Biochem. 16: 359-364.

14. Sinnhuber, R. A., and T. C. Yu. 1958. 2-Thiobarbituric acid method for the measurement of rancidity in fishery products. II. The quantitative determination of malonaldehyde. Food Technol. 12: 9-12.

15. Tollefson, D. M., J. R. Feagler, and P. W. Majerus. 1974. The binding of thrombin to the surface of human platelets. J. Biol. Chem. 249: 2646-2651.

16. Born, G. V. R., and M. J. Cross. 1963. The aggregation of blood platelets. J. Physiol. (Lond.). 168: 178195.

17. Salzman, E. W. 1972. Cyclic AMP and platelet function. N. Engl. J. Med. 286: 358-363.

18. Hamberg, M., J. Svensson, T. Wakabayashi, and B. Samuelsson. 1974. Isolation and structure of two prostaglandin endoperoxides that cause platelet aggregation. Proc. Natl. Acad. Sci. U. S. A. 71: 345-349.

19. Hamberg, M., J. Svensson, and B. Samuelsson. 1975. Thromboxanes: A new group of biologically active compounds derived from prostaglandin endoperoxides. Proc. Natl. Acad. Sci. U. S. A. 72: 2994-2998.

20. Fong, K-L., P. B. McCay, J. L. Poyer, B. B. Keele, and H. Misra. 1973. Evidence that peroxidation of lysosomal membranes is initiated by hydroxyl free radicals produced during flavin enzyme activity. J. Biol. Chem. 248: 7792-7797.

21. Kellogg, E. W., III, and I. Fridovich. 1975. Superoxide, hydrogen peroxide, and singlet oxygen in lipid peroxidation by a xanthine oxidase system. J. Biol. Chem. 250: 8812-8817.

22. Dahle, L. K., E. G. Hill, and R. T. Holman. 1962. The thiobarbituric acid reaction and the autoxidation of polyunsaturated fatty acid methyl esters. Arch. Biochem. Biophys. 98: 253-261.

23. Oette, K., M. L. Peterson, and R. L. McAuley. 1963. A highly sensitive method for measurement of lipid hydroperoxides by iodimetry and amperometric endpoint. J. Lipid Res. 4: 212-215.

24. Gershman, H., E. Powers, L. Levine, and H. Van Vunakis. 1972. Radioimmunoassay of prostaglandins, angiotensin, digoxin, morphine and adenosine- $3^{\prime}-5^{\prime}$-cyclic monophosphate with nitrocellulose membranes. Prostaglandins. 1: 407-423.

25. Brodie, G. N., N. L. Baenziger, L. R. Chase, and P. W. Majerus. 1972. The effects of thrombin on adenyl cyclase activity and a membrane protein from human platelets. J. Clin. Invest. 51: 81-88.

26. Droller, M. J., and S. M. Wolfe. 1972. Thrombininduced increase in intracellular cyclic $3^{\prime}, 5^{\prime}$-adenosine monophosphate in human platelets. J. Clin. Invest. 51: 3094-3103.

27. Haslam, R. J. 1975. Roles of cyclic nucleotides in platelet function. Biochemistry and Pharmacology of Platelets. CIBA Found. Symp. 35: 121-151.

28. Thomas, D. P. 1968. The role of platelet catecholamines in the aggregation of platelets by collagen and thrombin. In Platelets in Hememostasis. E. Hagen, W. Wechsler, and F. Zilliken, editors. A6. Karger, Basel. 129-134.

29. Niewiarowski, S., and D. P. Thomas. 1966. Platelet aggregation by ADP and thrombin. Nature (Lond.). 212: $1544-1547$.

30. Babior, B. M., J. T. Curnutte, and R. S. Kipnes. 1975. Pyridine nucleotide-dependent superoxide production by a cell-free system from human granulocytes. J. Clin. Invest. 56: 1035-1042. 